\title{
CONSIDERING MATERIAL CYCLES FOR A TRANSITION TO LOW-CARBON ENERGY SYSTEMS IN AOTEAROA/NEW ZEALAND: A SYSTEMATIC REVIEW
}

\author{
ISABELLA PIMENTEL PINCELLI, ALAN C. BRENT \& JAMES HINKLEY \\ Sustainable Energy Systems, Faculty of Engineering, Victoria University of Wellington, New Zealand
}

\begin{abstract}
The decarbonisation of energy systems plays a central role in climate change mitigation strategies. Yet, the implementation of new energy infrastructure increases material demand, especially metals, and poses a challenge with managing their end-of-life. However, it is not yet clear to what extent integrated analyses of energy and material systems have been undertaken for the New Zealand context. This paper provides a systematic literature review to inform how material analyses have been incorporated in the planning of low-carbon energy systems in New Zealand. The results show that research efforts have forecasted low-carbon energy systems and modelled some of the infrastructure required, as well as the associated lifecycle emissions considering scenarios of different renewable electricity mixes and of improvements in energy efficiency. However, material systems - whether virgin material demand or implications for recycling - have not been considered in low-carbon energy pathways for New Zealand. We recommend energy and material systems analyses for New Zealand should become more integrated to inform better policy and decision-making. This could be achieved by developing a model that integrates energy system modelling with dynamic stock-flow models and prospective lifecycle analysis. Keywords: energy system, material system, climate change mitigation, metal demand, lifecycle.
\end{abstract}

\section{INTRODUCTION}

Strategies to decarbonise energy systems and improve energy and material efficiencies can promote sustainable development; renewable energy systems address fossil fuel depletion while material efficiency reduces virgin material demand and emissions associated with the production value chain. The transition towards an energy system that is more reliant on renewable resources demands large quantities of resources and materials, and especially metals [1]. Material efficiency, on the other hand, can reduce resource extraction and waste generation leading to energy and emissions savings [2]. Therefore, the transition requires the careful management of the supply chains and end-of-life of alternate technologies and infrastructure that will be introduced in the energy system.

Indeed, the scientific literature points out the importance of integrating energy and material systems analyses when forecasting climate mitigation strategies. Integrated assessment pathways overlooked material cycles and misrepresented life-cycle impacts of energy technologies [3]. Energy system models should consider the whole process chain of emissions [4]. Thus, material cycles are an important aspect to be regarded in the transformation paths. Energy system models and material flow models could be coupled to assess the impacts of recycling over future energy system pathways [5].

In terms of the New Zealand context, the country ratified the Paris Agreement and, in 2019, introduced the Zero Carbon Amendment Act setting the following emissions targets for 2050: to reduce to zero all net emissions, except for biogenic methane [6]. New Zealand has the third highest share of renewable electricity generation in OECD countries; in 2019, the share was $82.4 \%$ [7]. However, the share of renewables in total primary energy was only $39.5 \%$ in 2019 [7]. New Zealand's gross domestic GHG emissions per capita was among the 
five highest in the OECD countries in 2017 [8]. The New Zealand economy is tradedependent and relies on international markets. However, the country's policies on reducing GHG emissions overlook lifecycle emissions and the embodied emissions of imported goods and services [9].

Many countries, including New Zealand, have been modelling and forecasting energy systems to support and understand the transition to a low-carbon economy and mitigate climate change. It is, however, not clear how material cycles have been integrated - or even considered - in low-carbon pathways. The objective of the paper is to provide a critical systematic review focussed on New Zealand, in terms of how material cycles have been included in energy system analysis and provide insights on how energy and material systems could become more integrated.

\section{METHOD}

A systematic literature review was performed to evaluate how New Zealand has addressed material cycles in the low-carbon energy transition.

The literature was searched using the Scopus database in August 2021. The keywords used for the literature search contained the concepts of energy systems, material systems, New Zealand, and future planning. The keywords used were the following - asterisks (*) were used to replace multiple characters in a word: energy plan* (energy plan, energy plans, energy planning), energy system*, energy model*, energy framework, electricity plan*, transport energy sector, renewable*, power generation, wind energy, solar energy, geothermal energy, hydropower, biogas, biofuel, hydrogen fuel, decarbonise, decarbonize, low-carbon, energy transition, virtual energy, indirect energy, embodied energy, embedded energy, energy footprint, life-cycle, lifecycle, life cycle, LCA, material system*, material efficiency, material flow*, MFA, material demand, supply chain, product system*, commodity*, industrial symbiosis, circular economy, recycling, resource management, waste management, end-of-life, solar PV, wind turbine, hydro turbine, batter*, electric vehicle*, metal*, aluminium, aluminium, glass, plastic, paper, solid waste, New Zealand, Aotearoa, pathway*, forecast, future, scenario*, plan*, goal*, target*, simulation, and route.The selected period for the literature search was from 2011 to 2021. In addition, "grey literature" in the form of governmental and business reports was also assessed.

Abstracts were screened for relevance, and then a refined eligibility assessment was conducted based on a full-text review. Only studies available in full text and about New Zealand were selected. Other criteria used were whether the study was about any low-carbon energy system strategy, and whether it included any material or product analysis. The total number of included studies was 41.

Finally, data from the included studies were extracted and analysed, in terms of the type of material analysis performed in the context of the low-carbon energy transition for New Zealand. Previous analyses of energy and material systems in New Zealand were synthesised in material demand for low-carbon strategies, and in lifecycle impacts of low-carbon technologies.

\section{RESEARCH FINDINGS}

\subsection{Material demand for low-carbon strategies}

No estimation of New Zealand's potential share on future global demand of metals for the country's low-carbon energy transition was identified in the literature, although the Climate Change Commission [10] acknowledged that many low-carbon technologies demand metals. 
Another noted weakness in the reviewed literature was an absence of studies about the endof-life phase of low-carbon technologies in terms of the quantity of waste generated and implications for recycling. On the other hand, several reviewed studies analysed the infrastructure required for a low-carbon transition in the electricity, transport and building sectors (see Table 1).

Table 1: Reviewed literature about infrastructure required for low-carbon strategies.

\begin{tabular}{|c|c|c|c|}
\hline Sector & Area & Specification of the study & Source \\
\hline \multirow{5}{*}{ Electricity } & Local & $\begin{array}{l}\text { Optimised micro-grid energy systems. Optimal } \\
\text { number of renewable generation plants; } \\
\text { transformer; electrolyser; battery banks; capacitor } \\
\text { bank; inverter. }\end{array}$ & {$[11]-[15]$} \\
\hline & Local & $\begin{array}{l}\text { Reviewed community energy initiatives and } \\
\text { reported some of infrastructure planned. }\end{array}$ & [16] \\
\hline & Local & Optimal number of tidal turbines. & {$[17]$} \\
\hline & Local & $\begin{array}{l}\text { Presented an historical evolution of the } \\
\text { infrastructure of geothermal plant. }\end{array}$ & {$[18]$} \\
\hline & National & Future projects to increase electricity transmission. & [19] \\
\hline \multirow{10}{*}{ Transport } & National & Modelled hydrogen heavy-duty vehicles uptake. & [20] \\
\hline & Local & $\begin{array}{l}\text { Modelled electrification of a bus route and the } \\
\text { number of electric buses. }\end{array}$ & {$[21]$} \\
\hline & Regional & $\begin{array}{l}\text { Optimised freight network to improve energy } \\
\text { efficiency. Forecasted number of railway tracks, } \\
\text { cranes and forklifts at freight terminals. }\end{array}$ & {$[22]$} \\
\hline & Local & $\begin{array}{l}\text { Evaluated programme on investing in cycleways } \\
\text { and walkways infrastructure to reduce emissions. }\end{array}$ & {$[23]$} \\
\hline & Local & $\begin{array}{l}\text { Evaluated perceptions for increasing cycling, they } \\
\text { found that improving infrastructure might be a } \\
\text { pathway. }\end{array}$ & {$[24]$} \\
\hline & National & $\begin{array}{l}\text { Simulated an electricity network considering EV } \\
\text { batteries as grid storage, modelled uptake of EV. }\end{array}$ & {$[25]$} \\
\hline & National & $\begin{array}{l}\text { Modelled the share of EV fleet in New Zealand for } \\
\text { light and heavy vehicles. }\end{array}$ & {$[10]$} \\
\hline & National & Created scenarios of electrification of transport. & [26] \\
\hline & National & $\begin{array}{l}\text { Simulated uptake of low-emission vehicles (light } \\
\text { and heavy-duty), considered consumer preferences. }\end{array}$ & {$[27]$} \\
\hline & Local & $\begin{array}{l}\text { Analyse the installation of solar panel in a rooftop } \\
\text { of a bus to save energy. }\end{array}$ & {$[28]$} \\
\hline \multirow[t]{2}{*}{ Building } & National & $\begin{array}{l}\text { Modelled light demand and efficient lighting } \\
\text { technology uptake. Forecasted number of different } \\
\text { bulbs. }\end{array}$ & [29] \\
\hline & National & $\begin{array}{l}\text { Analysed factors that affect residential PV uptake } \\
\text { in New Zealand. }\end{array}$ & [30] \\
\hline
\end{tabular}

Some of the studies assessed aspects of the infrastructure required for a low carbon transition, although a comprehensive study into all infrastructure required at a national level is lacking. A key transition pathway for the electricity sector relies on expanding renewable 
generation and upgrading transmission and distribution grids [10]. The reviewed studies have analysed the infrastructure required for renewable energy generation, such as the required number of turbines for a tidal energy power plant [17]. Other reviewed studies estimated the infrastructure required to transition to low-carbon micro-grid electricity systems, not considering the upgrade of the electricity transmission system [11]-[15]. On the other hand, Transpower [19], which operates the national transmission network, presented the current components of the transmission network in the country and future projections to increase electricity transfer and meet future demand.

Regarding the transport sector, there is no specific analysis of material demand for the future transport electrification in New Zealand. Although the sizes of New Zealand's electric vehicles fleets have been forecasted for electric heavy-duty vehicles [20], [26], and for passenger vehicles [10], [25], [26]. These studies used different assumptions for calculating electric vehicle uptake in the country.

Global materials demand for low-carbon energy transitions has recently been modelled. Low-carbon energy transition scenarios from integrated assessment models or from energy system models were used to translate future material demand by combining the scenarios with Input-Output analysis [31], lifecycle inventories (LCIs) [32], dynamic material flow analysis, or dynamic stock-flow modelling [1], [33], [34]. Input-Output models aggregate information in economic flows, so information were disaggregated to model physical flows of commodities, which, however, can lead to model biases and discrepant results [31]. In lifecycle assessment models, it is difficult to discern what part of material demand stems from the electricity generation capacity and what stems from upstream production [1]. Indeed, a strategy to disaggregate LCI information of material intensity from electricity production into construction, decommission and operation was developed to calculate future material demand [32]. However, LCIs might consider different system boundaries, and disaggregating information can generate discrepancies in material demand [32]. On the other hand, dynamic material flow analysis or dynamic stock-flow models model the actual physical flows and stocks of materials and can produce more accurate estimations of the future material demand of low-carbon technologies.

Regarding the end-of-life management of low-carbon technologies for New Zealand, no study was identified that specifically analysed this aspect. However, the Climate Change Commission [10] acknowledged that managing the end-of-life of low-carbon technologies can be challenging, as they are not (yet) easily recycled and it is difficult to dispose of them. Since low-carbon technologies will demand large quantities of metals, recovering metals will become even more relevant in the future. Recycling will be crucial for future resource availability, as it is a long-term option to mitigate resource scarcity. Nevertheless, it is insufficient for short-term demand [35]. Moreover, recycling can save energy and emissions, although there are constraints for recycling. Indeed, there are worldwide examples of models that considered circular economy strategies when modelling the material demand for lowcarbon energy system, such as substitution [33], lifetime extension, reuse, and recycling [35].

The transition to low-carbon technologies will increase demand of metals, minerals, and rare earth materials. Thus, it is very important to forecast material demand when planning a low-carbon transition, as well as analyse material supply together with circular economy strategies. The decarbonisation of energy system is essential for a sustainable future, and it should be planned alongside efficient material resources systems. 


\subsection{Lifecycle impacts of low-carbon strategies}

Low-carbon energy technologies have energy and emissions embodied in their materials and manufacturing processes. The indirect emissions are generally considered to be modest compared with the impact of avoiding fossil fuel combustion during the use phase [36]. However, it might become relevant in a low-carbon economy [36]. The study of lifecycle impacts of low-carbon technologies for New Zealand is a strength in the body of knowledge (see Table 2). Some of the reviewed studies performed life cycle assessments (LCAs) of products and processes involving low-carbon strategies, while others were more focused on embodied energy and emissions. The reviewed studies analysed lifecycle impacts for the electricity and transport sectors at a national level, whereas lifecycle impacts for the building, industry, and other sectors were more specific to an establishment.

The reviewed studies evaluated lifecycle emissions of renewable electricity generation using different approaches and assuming different renewables uptake scenarios for New Zealand. In Crossland et al. [37], scenarios of renewable electricity generation to meet electricity demand were created and lifecycle emissions of electricity systems were estimated using lifecycle carbon intensity factors for renewable plants as provided by the Intergovernmental Panel on Climate Change [38]. Energy Return on Investment (EROI) was combined with Carbon Emission Pinch Analysis (CEPA) to account for direct and embodied emissions of renewable generation plants, considering future scenarios of electricity demand and supply [39], [41]. EROI was linked to Energy Return on Carbon calculations in order to estimate emissions of current and consented wind energy farms in New Zealand [40]. The approaches used to calculate emissions of the transition to renewable electricity considered a stationary behaviour of emissions. No dynamic lifecycle emission model considering changes during low-carbon energy transitions was identified for New Zealand.

Because of the high share of renewable electricity in New Zealand, the impacts of electric appliances during usage were usually small compared with the impacts at their production and disposal, such as the impacts of electric bikes in [47]. An EV in New Zealand reduces about $60 \%$ of emissions across its full lifecycle when compared to an equivalent internal combustion engine vehicle (ICEV) and reduces $80 \%$ of emissions during the use phase [44]. Considering the uptake of renewable electricity generation, the emissions during the use phase could change and get even lower. Likewise, in the building sector, environmental impacts of low-carbon strategies are mainly due to producing materials and most of the impacts reduce in the operational phase [50]. Considering the high embodied energy of materials used in the building sector, studies have analysed the benefits of reuse, recovery or recycling those materials [49], [52]. The building sector is in the early stage of a low-carbon transition [48], and the Ministry of Business Innovation and Employment [60] is in the process of developing the Building for Climate Change programme, which will consider the whole-of-life embodied emissions.

In addition to changes in the use phase, the lifecycle emissions in the production and endof-life stages might also change over time. In the mining process, easily mined ore deposits have declined [61] and ore grades from existing mined deposits have decreased [62]. Although new mining deposits could be discovered, it is expected that the energy needed for mining and processing virgin metals will increase [61]. Until a transition to a low-carbon energy system is not reached, the energy used for metal extraction will come from fossil fuels [61], which have high levels of associated emissions. Moreover, the end-of-life management of low-carbon energy technologies might change, and recycling of metals might increase and alleviate long-term resource extractions and associated emissions. 
Table 2: Reviewed literature about lifecycle impacts of low-carbon strategies.

\begin{tabular}{|c|c|c|c|}
\hline Sector & Area & Specification of the study & Source \\
\hline \multirow{5}{*}{ Electricity } & National & $\begin{array}{l}\text { Assessed electricity decarbonization scenarios and used } \\
\text { lifecycle carbon intensity factors from [38]. }\end{array}$ & [37] \\
\hline & National & $\begin{array}{l}\text { Calculated carbon footprint of renewable generation plants } \\
\text { considering different generation scenarios. }\end{array}$ & {$[39]$} \\
\hline & National & $\begin{array}{l}\text { Estimated the embedded energy and carbon emissions of } \\
\text { current and consented wind farms. }\end{array}$ & [40] \\
\hline & National & $\begin{array}{l}\text { Calculated emissions of electricity system, analysing } \\
\text { scenarios of renewables uptake. }\end{array}$ & [41] \\
\hline & National & $\begin{array}{l}\text { Measured energy of emergy generation. Emergy is all the } \\
\text { energy used to produce a product or service, usually, it is } \\
\text { expressed in solar equivalents. }\end{array}$ & [42] \\
\hline \multirow{5}{*}{ Transport } & National & $\begin{array}{l}\text { Analysed acceptability of transport emissions reduction } \\
\text { policies. }\end{array}$ & [43] \\
\hline & National & Life cycle assessment of electric vehicles. & [44] \\
\hline & National & Analysed emissions reductions in the transport sector. & [45] \\
\hline & National & $\begin{array}{l}\text { Analysed pathways for sustainability of road transport. } \\
\text { Considered lifecycle impacts of transport. }\end{array}$ & [46] \\
\hline & Local & $\begin{array}{l}\text { Life cycle assessment, cradle-to-grave scope, of a greater } \\
\text { uptake of E-bikes displacing ICE cars. }\end{array}$ & {$[47]$} \\
\hline \multirow{7}{*}{ Building } & National & $\begin{array}{l}\text { Reviewed approaches used in New Zealand to assess } \\
\text { embodied emissions at building sector. }\end{array}$ & [48] \\
\hline & Local & $\begin{array}{l}\text { Calculated embodied emissions of materials; analysed } \\
\text { emissions benefits of reuse, recovery or recycling. }\end{array}$ & [49] \\
\hline & Local & $\begin{array}{l}\text { Calculated environmental impacts of refurbishment, } \\
\text { considering improvement of construction practice, PV } \\
\text { usage, and increase of renewables share on electricity. }\end{array}$ & {$[50]$} \\
\hline & Local & $\begin{array}{l}\text { Calculated environmental impacts of a deep energy } \\
\text { efficiency refurbishment. }\end{array}$ & [51] \\
\hline & Local & $\begin{array}{l}\text { Estimated embodied energy/emissions saved by recycling } \\
\text { materials from a deconstruction site. }\end{array}$ & {$[52]$} \\
\hline & Local & $\begin{array}{l}\text { Optimised photovoltaic-plus-battery for residences, } \\
\text { considered embodied energy of PV and battery. }\end{array}$ & [53] \\
\hline & Local & Calculated embodied energy of a house. & [54] \\
\hline \multirow{3}{*}{ Industry } & Local & $\begin{array}{l}\text { LCA of a cheese factory, considered scenarios of } \\
\text { introducing geothermal and biomass energy. }\end{array}$ & [55] \\
\hline & Local & $\begin{array}{l}\text { LCA of dairy sector, considered scenarios of moving from } \\
\text { coal, natural gas towards biomass energy. }\end{array}$ & {$[56]$} \\
\hline & Local & $\begin{array}{l}\text { Energy efficiency of using bark (by-product from wood- } \\
\text { processing) to produce briquettes and tannin. }\end{array}$ & [57] \\
\hline \multirow[t]{2}{*}{ Other } & Local & $\begin{array}{l}\text { Analysed indirect and direct energy to produce organic } \\
\text { fruits at an orchard. }\end{array}$ & [58] \\
\hline & National & Reviewed energy efficiency strategies in NZ. & [59] \\
\hline
\end{tabular}

Prospective LCAs have been developed worldwide to account for future lifecycle impacts of emerging technologies. The future is inherently uncertain, and a common approach at LCA 
studies is to create future scenarios based on specific assumptions about the future [63]. At the scenario generation, studies usually use multiple databases for the assumption of future technological changes, which make it difficult to trace all the assumptions made [63]. In addition, when comparing different technologies, disparate databases could lead in an inconsistent LCA comparison, because of the different assumptions and system boundaries [64]. It is preferable to use a single analytical structure, in which the same background data for common processes among technologies are used [64]. Existing models project future technological, economic, social, and environmental changes, they are based in approaches such as optimisation, simulation, or general equilibrium, and could be used to complement prospective LCAs. However, those models might not consider all possible dynamic changes from all sectors. Recent studies integrated information from future energy scenarios from Integrated assessment models and energy systems models with prospective LCAs [63], [64], and that is a possible solution for LCAs to consider dynamic changes and overcome subjective assumptions at scenario generation. Other studies first performed prospective LCAs and integrated the results generated at prospective LCAs into integrated assessment models [65] and energy system models [66] aiming to assess long-term environmental impacts of energy pathways.

The reviewed literature about lifecycle impacts of low-carbon strategies for New Zealand present snapshots in time, and this limitation is related to the approaches that were used. The transition towards more renewable energy with sustainable supply chains might be a complex situation, with dynamic changes over time, multiple players, and interdependencies among different systems [67]. However, no dynamic studies assessing lifecycle emission of new energy systems were identified. In addition, LCA approaches are not able to assess actual material demand, and energy system or economy-wide emissions [36]. Therefore, a model to investigate the total material demand and emissions of a low-carbon energy transition, considering all lifecycle stages and dynamic changes, is lacking in the body of knowledge.

\subsection{Recommendations for New Zealand's low-carbon transition models}

Our review showed a lack of analysis about material demand for a low-carbon transition in New Zealand, and that lifecycle emissions analysis could be developed to consider dynamic changes in the system. In addition, New Zealand pursue recent energy system models, such as the Climate Change Commission model [10] and the TIMES-NZ model [68]. Energy system models consider changes throughout the economy but overlook material cycles and indirect emissions. Thus, there is an opportunity to develop a model to include material demand and lifecycle emissions for the low-carbon transition, considering the characteristics of the country.

There are recent worldwide efforts to analyse the implications of low-carbon transition on material systems. As previously discussed, integrated assessment models or energy systems models have been combined with dynamic stock models to analyse future material demand, and with prospective LCAs to analyse future environmental impacts. However, usually, they are global models and either focus on material demand or lifecycle emissions. Thus, developing a model that encompasses material demand and the implications of the circular economy in the supply chain together with environmental impacts could expand the understanding of low-carbon transitions [69].

Therefore, we suggest the development of a national model for New Zealand to integrate in one framework dynamic material supply-demand and prospective lifecycle emissions of low-carbon strategies. New Zealand has energy models that could be augmented to integrate energy planning with material cycles and lifecycle emissions. A possible solution for 
including material cycles in low-carbon pathways is to integrate them with dynamic stockflow models and consider the implication of different circular strategies in the material supply. In order to account for future changes in lifecycle emissions of low-carbon technologies, prospective LCAs can be integrated with low-carbon pathways. In addition, to evaluate emissions flows, lifecycle emissions can be linked to material flows.

\section{CONCLUSION}

The decarbonisation of energy systems plays a central role in climate change actions and material analyses are very pertinent in this context. Although low-carbon technologies contribute significantly to reducing emissions in their usage phase, they require an increase in resource consumption during build out and have associated environmental impacts during their production and end-of-use phases. Recycling could relieve constraints around the supply of materials in the long-term. Therefore, the efficient use of the most sustainable and least polluting technologies available is required for a well-managed low-carbon transition. This systematic literature review was unable to identify a single study of material demand for future low-carbon technologies to be implemented in New Zealand, nor any about endof-life management of low-carbon technologies, in terms of quantity of waste generated and recycling. On the other hand, many studies have analysed lifecycle impacts of low-carbon energy systems in New Zealand. However, lifecycle emissions have been calculated using static approaches, and the assumption of future scenarios represent only snapshots of lifecycle emissions using historical data, and no dynamic changes have been modelled. Developing a modelling framework that incorporates energy systems with material cycles is critically important in order to have a comprehensive understanding of low-carbon transitions. A possible solution is to develop dynamic stock-flows and prospective lifecycle emissions models integrated with energy system models.

\section{ACKNOWLEDGEMENT}

This study was supported by the Wellington Doctoral Scholarship from the Victoria University of Wellington, New Zealand.

\section{REFERENCES}

[1] Deetman, S., Pauliuk, S., Van Vuuren, D.P., Van Der Voet, E. \& Tukker, A., Scenarios for demand growth of metals in electricity generation technologies, cars, and electronic appliances. Environmental Science and Technology, 52, pp. 4950-4959, 2018. https://doi.org/10.1021/acs.est.7b05549.

[2] Pauliuk, S. \& Heeren, N., Material efficiency and its contribution to climate change mitigation in Germany: A deep decarbonization scenario analysis until 2060. Journal of Industrial Ecology, 25, pp. 479-493, 2021. https://doi.org/10.1111/jiec.13091.

[3] Pauliuk, S., Arvesen, A., Stadler, K. \& Hertwich, E.G., Industrial ecology in integrated assessment models. Nature Climate Change, 7, pp. 13-20, 2017.

[4] Lopion, P., Markewitz, P., Robinius, M. \& Stolten, D., A review of current challenges and trends in energy systems modeling. Renewable and Sustainable Energy Reviews, 96, pp. 156-166, 2018. https://doi.org/10.1016/j.rser.2018.07.045.

[5] Kullmann, F., Markewitz, P., Stolten, D. \& Robinius, M., Combining the worlds of energy systems and material flow analysis: A review. Energy, Sustainability and Society, 11, p. 13, 2021. https://doi.org/10.1186/s13705-021-00289-2.

[6] New Zealand Government, Climate Change Response (Zero Carbon) Amendment Act 2019. http://www.legislation.govt.nz/act/public/2019/0061/latest/LMS183736.html. Accessed on: 17 Aug. 2021. 
[7] Ministry of Business Innovation and Employment, Energy in New Zealand, Energy \& Buildings Trends, 2020. https://www.mbie.govt.nz/dmsdocument/11679-energy-innew-zealand-2020. Accessed on: 17 Aug. 2021.

[8] OECD, OECD Environmental Performance Reviews: New Zealand 2017, 2017. https://doi.org/10.1787/9789264268203-en.

[9] Malik, A., Chandrakumar, C., Lenzen, M. \& Mclaren, S.J., Re-Examining climate policies for pathways to a zero carbon future. Environmental Science and Technology, 55, 1-3, 2021. https://doi.org/10.1021/acs.est.0c03424.

[10] Climate Change Commission, A low emission future for Aotearoa, 2021. https://ccc-production-media.s3.ap-southeast-2.amazonaws.com/public/Inaia-tonunei-a-low-emissions-future-for-Aotearoa/Inaia-tonu-nei-a-low-emissions-future-forAotearoa.pdf. Accessed on: 17 Aug. 2021.

[11] Mohseni, S., Brent, A.C., Kelly, S., Browne, W.N. \& Burmester, D., Strategic design optimisation of multi-energy-storage-technology micro-grids considering a two-stage game-theoretic market for demand response aggregation. Applied Energy, 287, 116563, 2021. https://doi.org/10.1016/J.APENERGY.2021.116563.

[12] Mohseni, S. \& Brent, A.C., Economic viability assessment of sustainable hydrogen production, storage, and utilisation technologies integrated into on- and off-grid microgrids: A performance comparison of different meta-heuristics. International Journal of Hydrogen Energy, 45, pp. 34412-34436, 2020.

[13] Mohseni, S., Brent, A.C. \& Burmester, D., Power quality considerations in the planning phase of stand-alone wind-powered micro-grids. Proceedings of International Conference on Harmonics and Quality of Power, 2020.

[14] Mohseni, S., Brent, A.C. \& Burmester, D., A comparison of metaheuristics for the optimal capacity planning of an isolated, battery-less, hydrogen-based micro-grid. Applied Energy, 259, 114224, 2020.

[15] Mohseni, S., Brent, A.C., Burmester, D. \& Browne, W., A game-theoretic approach to model interruptible loads: Application to micro-grid planning. 2020 IEEE Power and Energy Society General Meeting (PESGM).

[16] Roberts, R., Brent, A. \& Hinkley, J., Reviewing the impacts of community energy initiatives in New Zealand. Kōtuitui: New Zealand Journal of Social Sciences, 16, pp. 45-60, 2021. https://doi.org/10.1080/1177083X.2021.1877161.

[17] Vennell, R., Major, R., Zyngfogel, R., Beamsley, B., Smeaton, M., Scheel, M. \& Unwin, H., Rapid initial assessment of the number of turbines required for large-scale power generation by tidal currents. Renewable Energy, 162, pp. 1890-1905, 2020.

[18] DiPippo, R., Geothermal power plants: Evolution and performance assessments. Geothermics, 53, pp. 291-307, 2015.

[19] Transpower, Transmission Planning Report 2020, 2020. https://www.transpower.co.nz/resources/whakamana-i-te-mauri-hiko-empoweringour-energy-future. Accessed on: 17 Aug. 2021.

[20] Kotze, R., Brent, A.C., Musango, J., De Kock, I. \& Malczynski, L.A., Investigating the investments required to transition New Zealand's heavy-duty vehicles to hydrogen. Energies, 14, p. 1646, 2021. https://doi.org/10.3390/en14061646.

[21] Arif, S.M., Lie, T.T., Seet, B.C., Ahsan, S.M. \& Khan, H.A., Plug-in electric bus depot charging with PV and ESS and their impact on LV feeder. Energies, 13, p. 2139, 2020. https://doi.org/10.3390/en13092139.

[22] Gallardo, P., Murray, R. \& Krumdieck, S., A sequential optimization-simulation approach for planning the transition to the low carbon freight system with case study in the North Island of New Zealand. Energies, 14, p. 3339, 2021. 
[23] Howden-Chapman, P., Keall, M., Whitwell, K. \& Chapman, R., Evaluating natural experiments to measure the co-benefits of urban policy interventions to reduce carbon emissions in New Zealand. Science of the Total Environment Journal, 700, 134408, 2020. https://doi.org/10.1016/j.scitotenv.2019.134408.

[24] Hopkins, D. \& Mandic, S., Perceptions of cycling among high school students and their parents. International Journal of Sustainable Transportation, 11, pp. 342-356, 2017.

[25] Monigatti, P., Apperley, M. \& Rogers, B., Improved grid integration of intermittent electricity generation using electric vehicles for storage: A simulation study. 2012 International Green Computing Conference (IGCC), 2012.

[26] Ministry of Business Innovation and Employment, Electricity demand and generation scenarios: Scenario and results summary, 2019. https://www.mbie.govt.nz/ dmsdocument/5977-electricity-demand-and-generation-scenarios. Accessed on: 17 Aug. 2021.

[27] Shafiei, E., Leaver, J. \& Davidsdottir, B., Cost-effectiveness analysis of inducing green vehicles to achieve deep reductions in greenhouse gas emissions in New Zealand. Journal of Cleaner Production, 150, pp. 339-351, 2017.

[28] Ur Rehman, N., Hijazi, M. \& Uzair, M., Solar potential assessment of public bus routes for solar buses. Renewable Energy, 156, pp. 193-200, 2020.

[29] Dortans, C., Jack, M.W., Anderson, B. \& Stephenson, J., Lightening the load: quantifying the potential for energy-efficient lighting to reduce peaks in electricity demand. Energy Efficiency, 13, pp. 1105-1118, 2020.

[30] Ford, R., Walton, S., Stephenson, J., Rees, D., Scott, M., King, G., Williams, J. \& Wooliscroft, B., Emerging energy transitions: PV uptake beyond subsidies. Technological Forecasting and Social Change, 117, pp. 138-150, 2017.

[31] Huang, K. \& Eckelman, M.J., Appending material flows to the National Energy Modeling System (NEMS) for projecting the physical economy of the United States Gold Contribution Accessibility Gold. Journal of Industrial Ecology, 2020.

[32] Boubault, A., Kang, S. \& Maïzi, N., Closing the TIMES integrated assessment model (TIAM-FR) raw materials gap with life cycle inventories. Journal of Industrial Ecology, 23, pp. 587-600, 2019.

[33] Watari, T., Nansai, K., Nakajima, K. \& Giurco, D., Sustainable energy transitions require enhanced resource governance. Journal of Cleaner Production, 312, 127698, 2021. https://doi.org/10.1016/J.JCLEPRO.2021.127698.

[34] Ren, K., Tang, X., Wang, P., Willerström, J. \& Höök, M., Bridging energy and metal sustainability: Insights from China's wind power development up to 2050. Energy, 227, 120524, 2021. https://doi.org/10.1016/J.ENERGY.2021.120524.

[35] Månberger, A. \& Stenqvist, B., Global metal flows in the renewable energy transition: Exploring the effects of substitutes, technological mix and development. Energy Policy, 119, pp. 226-241, 2018. https://doi.org/10.1016/j.enpol.2018.04.056.

[36] Daly, H.E., Scott, K., Strachan, N. \& Barrett, J., Indirect $\mathrm{CO}_{2}$ emission implications of energy system pathways: Linking IO and TIMES models for the UK. Environmental Science and Technology, 49, pp. 10701-10709, 2015.

[37] Crossland, A., Scoles, K., Wang, A., Groves, C. \& Sun, S., Assessment of electricity decarbonization scenarios for New Zealand and Great Britain using a plant dispatch and electrical energy storage modelling framework. Energies, 13, p. 2799, 2020.

[38] Contribution of Working Group III to the Fifth Assessment Report of the Intergovernmental Panel on Climate Change, Climate Change 2014 Mitigation of 
Climate Change. https://www.ipcc.ch/site/assets/uploads/2018/02/ipcc_wg3_ar5 full.pdf. Accessed on: 17 Aug. 2021.

[39] Walmsley, M.R.W., Walmsley, T.G. \& Atkins, M.J., Linking greenhouse gas emissions footprint and energy return on investment in electricity generation planning. Journal of Cleaner Production, 200, pp. 911-921, 2018.

[40] Walmsley, T.G., Walmsley, M.R.W. \& Atkins, M.J., Energy return on energy and carbon investment of wind energy farms: A case study of New Zealand. Journal of Cleaner Production, 167, pp. 885-895, 2017.

[41] Walmsley, M.R.W., Walmsley, T.G., Atkins, M.J., Kamp, P.J.J. \& Neale, J.R., Minimising carbon emissions and energy expended for electricity generation in New Zealand through to 2050. Applied Energy, 135, pp. 656-665, 2014.

[42] Patterson, M.G., Are all processes equally efficient from an emergy perspective? Analysis of ecological and economic networks using matrix algebra methods. Ecological Modelling, 226, pp. 77-91, 2012.

[43] Hasan, MA, Chapman, R. \& Frame, D.J., Acceptability of transport emissions reduction policies: A multi-criteria analysis. Renewable and Sustainable Energy Reviews, 133, 110298, 2020. https://doi.org/10.1016/j.rser.2020.110298.

[44] Energy Efficiency and Conservation Authority, Energy Efficiency and Conservation Authority Life Cycle Assessment of Electric Vehicles Final Report, 2015. https://www.eeca.govt.nz/assets/EECA-Resources/Research-papers-guides/ev-lcafinal-report-nov-2015.pdf. Accessed on: 17 Aug. 2021.

[45] Walmsley, M.R.W., Walmsley, T.G., Atkins, M.J., Kamp, P.J.J., Neale, J.R. \& Chand, A., Carbon emissions pinch analysis for emissions reductions in the New Zealand transport sector through to 2050. Energy, 92, pp. 569-576, 2015.

[46] Kelly, G., Avenues to sustainable road transport energy in New Zealand. International Journal of Sustainable Transportation, 10, pp. 505-516, 2016.

[47] Elliot, T., McLaren, S.J. \& Sims, R., Potential environmental impacts of electric bicycles replacing other transport modes in Wellington, New Zealand. Sustainable Production and Consumption, 16, pp. 227-236, 2018.

[48] Bui, T.T.P., Wilkinson, S., Domingo, N. \& Macgregor, C., Zero carbon building practices in Aotearoa, New Zealand. Energies, 14, p. 4455, 2021.

[49] Chandrakumar, C., McLaren, S.J., Dowdell, D. \& Jaques, R., A science-based approach to setting climate targets for buildings: The case of a New Zealand detached house. Building and Environment, 169, 106560, 2020.

[50] Ghose, A., Pizzol, M., McLaren, S.J., Vignes, M. \& Dowdell, D., Refurbishment of office buildings in New Zealand: Identifying priorities for reducing environmental impacts. The International Journal of Life Cycle Assessment, 24, pp. 1480-1495, 2019.

[51] Ghose, A., McLaren, S.J., Dowdell, D. \& Phipps, R., Environmental assessment of deep energy refurbishment for energy efficiency-case study of an office building in New Zealand. Building and Environment, 117, pp. 274-287, 2017.

[52] Zaman, A.U., Arnott, J., Mclntyre, K. \& Hannon, J., Resource harvesting through a systematic deconstruction of the residential house: A case study of the "Whole House Reuse" project in Christchurch, New Zealand. Sustainability, 10, p. 3430, 2018.

[53] Mason, I.G. \& Miller, A.J.V., Energetic and economic optimisation of islanded household-scale photovoltaic-plus-battery systems. Renewable Energy, 96, pp. 559573, 2016. https://doi.org/10.1016/J.RENENE.2016.03.048.

[54] Nsaliwa, D., Vale, R. \& Isaacs, N., Housing and transportation: Towards a multi-scale net zero emission housing approach for residential buildings in New Zealand. Energy Procedia, 75, pp. 2826-2832, 2015. 
[55] Tarighaleslami, A.H., Ghannadzadeh, A., Atkins, M.J. \& Walmsley, M.R.W., Environmental life cycle assessment for a cheese production plant towards sustainable energy transition: Natural gas to biomass vs. natural gas to geothermal. Journal of Cleaner Production, 275, 122999, 2020.

[56] Tarighaleslami, A.H., Kambadur, S., Neale, J.R., Atkins, M.J. \& Walmsley, M.R.W., Sustainable energy transition toward renewable energies in the New Zealand dairy industry: An environmental life cycle assessment. Chemical Engineering Transactions, 76, pp. 97-102, 2019. https://doi.org/10.3303/CET1976017.

[57] Wijeyekoon, S., Suckling, I., Fahmy, M., Hall, P. \& Bennett, P., Techno-economic analysis of tannin and briquette co-production from bark waste: A case study quantifying symbiosis benefits in biorefinery. Biofuels, Bioproducts and Biorefining, 2021.

[58] Page, G., Modelling sustainability: what are the factors that influence sustainability of organic fruit production systems in New Zealand? Organic Agriculture, 1, pp. 55-64, 2011. https://doi.org/10.1007/s13165-011-0005-4.

[59] Verma, P., Patel, N., Nair, N.-K.C. \& Brent, A.C., Improving the energy efficiency of the New Zealand economy: A policy comparison with other renewable-rich countries. Energy Policy, 122, pp. 506-517, 2018. https://doi.org/10.1016/j.enpol.2018.08.002.

[60] Ministry of Business Innovation and Employment, Building for climate change. https://www.building.govt.nz/getting-started/building-for-climate-change/. Accessed on: 17 Aug. 2021.

[61] Vidal, O., Goffé, B. \& Arndt, N., Metals for a low-carbon society. Nature Geoscience, 6, pp. 894-896, 2013. https://doi.org/10.1038/ngeo1993.

[62] Rötzer, N. \& Schmidt, M., Decreasing metal ore grades-Is the fear of resource depletion justified? Resources, 7, p. 88, 2018.

[63] Beltran, A.M. et al., When the background matters: Using scenarios from integrated assessment models in prospective life cycle assessment. Journal of Industrial Ecology, 24, pp. 64-79, 2018.

[64] Hertwich, E.G. et al., Integrated life-cycle assessment of electricity-supply scenarios confirms global environmental benefit of low-carbon technologies. PNAS, 112(20), pp. 6277-6282, 2015. https://doi.org/10.2307/26462807.

[65] Pehl, M., Arvesen, A., Humpenöder, F., Popp, A., Hertwich, E.G. \& Luderer, G., Understanding future emissions from low-carbon power systems by integration of lifecycle assessment and integrated energy modelling. Nature Energy, 2, pp. 939-945, 2017. https://doi.org/10.1038/s41560-017-0032-9.

[66] Vandepaer, L., Panos, E., Bauer, C. \& Amor, B., Energy system pathways with low environmental impacts and limited costs: Minimizing climate change impacts produces environmental cobenefits and challenges in toxicity and metal depletion categories. Environmental Science and Technology, 54, pp. 5081-5092, 2020.

[67] Saavedra, M.R.M., de O. Fontes, C.H. \& Freires, F.G.M., Sustainable and renewable energy supply chain: A system dynamics overview. Renewable and Sustainable Energy Reviews, 82, pp. 247-259, 2018. https://doi.org/10.1016/J.RSER.2017.09.033.

[68] Energy Efficiency and Conservation Authority (EECA), New Zealand Energy Scenarios TIMES-NZ 2.0. https://www.eeca.govt.nz/insights/new-zealand-energyscenarios-times-nz/. Accessed on: 17 Aug. 2021.

[69] Watari, T., Nansai, K., Nakajima, K., McLellan, B.C., Dominish, E. \& Giurco, D., Integrating circular economy strategies with low-carbon scenarios: Lithium use in electric vehicles. Environmental Science and Technology, 53, pp. 11657-11665, 2019. 